\title{
Do Covid-19 antibodies provide protecting for over 6 months?
}

\author{
Ozcan Deveci* \\ Department of Infectious Diseases and Clinical Microbiology, Batman Medical Park Hospital, Batman, Turkey
}

\section{Dear Editor,}

COVID-19 is a SARS CoV-2 type novel contagious human disease that affected several countries in the world. Serological tests are particularly valuable in epidemiological studies that aim to determine the immunity levels of the affected population, including both diagnosed and asymptomatic individuals. SARS Cov-2 virus includes 4 structural proteins. Among these, $\mathrm{S}$ and $\mathrm{N}$ proteins are the most studied antigens. All advancing techniques focused on detection of IgM and IgG antibodies [1,2]. Due to the short half-life of IgM antibodies (5-6 days) and the long half-life of IgG antibodies (21 days), IgM count decreases to undetectable levels, while IgG count is maintained further. Certain studies demonstrated that individuals who survived the COVID-19 infection continued to produce antibodies against significant sections of the virus for several months. However, the duration that these antibodies remain active and whether they are sufficient to protect against reinfection remains unclear. In a study, it was observed that COVID-19 antibodies protected most individuals from re-infection for six months [3]. In the antibody test we conducted on several healthcare professionals who were COVID-19-positive more than 6 months ago in our hospital demonstrated that the positivity continued and even increased in certain cases.

The conducted antibody test, namely Elecsys ${ }^{\oplus}$ Anti-SARS-CoV-2, is an in vitro immunochemistry test that qualitatively identifies SARSCoV-2 antibodies (including IgG) in human serum and plasma. The test was developed as an assistant in the determination of the immune system response to SARS-CoV-2.

However, further comprehensive studies are required to determine long-term immunity. We hope this letter would serve as a pioneer for future studies.

\section{References}

1. La Marca A, Capuzzo M, Paglia T, Roli L, Trenti T et al. (2020) Testing for SARSCoV-2 (COVID-19): a systematic review and clinical guide to molecular and serological in-vitro diagnostic assays. Reprod Biomed Online 41: 483-499. [Crossref]

2. Meyer B, Drosten C, Müller MA (2014) Serological assays for emerging coronaviruses: Challenges and pitfalls. Virus Res 194: 175-183. [Crossref]

3. Lumley SF, O'Donnell D, Stoesser NE, Matthews PC, Howarth A, et al. (2020) Antibodies to SARS-CoV-2 are associated with protection against reinfection. medRxiv preprint.
Copyright: (C2020 Deveci O. This is an open-access article distributed under the terms of the Creative Commons Attribution License, which permits unrestricted use, distribution, and reproduction in any medium, provided the original author and source are credited.
*Correspondence to: Ozcan Deveci, Department of Infectious Diseases and Clinical Microbiology, Batman Medical Park Hospital, Batman, Turkey, Tel: +90 4444484; E-mail: ozcandevecil@hotmail.com

Received: November 06, 2020; Accepted: November 20, 2020; Published: November 23, 2020 